\title{
ANALYSIS OF NATIONAL AND INTERNATIONAL AIMS AND INTERESTS IN TRADE
}

\author{
Floyd M. RIDDICK* AND Joseph W. Romita $†$
}

This introductory article on the "Analysis of National and International Aims and Interests in Trade" does not attempt an exhaustive study of any phase of foreign trade. It briefly discusses various aspects of trade relationships between countries, with particular reference to the trade interests and policies of the United States. It also summarizes trade characteristics influential in the determination of our National and International trade aims. For detailed analyses of special international trade problems, the reader is referred to the other articles in this symposium.

\section{Foreign and Domestic Trade Relationships}

Modern transportation and communication have forced a revolution in distribution, creating an international market for more and more local products. Paralleling this increase in the number of items and volume of foreign trade, the world has also been afflicted with a growth in new and more cumbersome trade barriers.

To make more domestic products "go international," the amount of trade between nations must grow; to make this possible, trade barriers must be curtailed or sliminated. Hence, the nations of the world in the postwar period should turn to fuller cooperation in the field of international trade.

If foreign trade or the lack thereof is a major source of conflict between nations -aggravated by unemployment, depressions, social unrest, and upheavals-then the aims and interests of national trade should be tied more closely with that of international. If nationalistic trade practices can only bring temporary advantages, each state should design its trade policies to accomplish international aims which are deemed advantageous to all over a long period of time.

- A.B., Duke University, I93I; M.A., Vanderbilt University, 1932; Ph.D., Duke University, 1935. Instructor in Political Science, American University, x936-7, x938-9. Legislative analyst (and editor of Governanental AfFairs) U. S. Chamber of Commerce, since I943. Editor: Congressional Intelligence, Inc. publications, 1942-43; Legislative Daily (U. S. C. of C.), since 1943. Author: Congressionar. Procendre (I94I). Contributor to political science and economic periodicals.

† B.S., American International College, x936; M.B.A., Wharton School of the University of Pennsylvania, 1937; advanced graduate studies in International Economics, Harvard University and New York University. Formerly, Registrar and Professor of Economics, Caney College; Professor of International Economics, St. John's University; Port Statistician for War Shipping Administration; Technical Adviser to United States Delegation to International Business Conference (Rye, N. Y., 1944). Presently, Secretary of United States Section of Inter-American Council of Commerce and Production and member of Foreign Commerce Department of the Chamber of Commerce of the U. S. Author: Operation of Export Trade ACT of 1918 (I937). Contributor to foreign trade periodicals. 
By the very nature of the world's economic structure, domestic trade cannot be . placed into one compartment and foreign trade into another. Indirectly domestic trade is to a large extent international, while the nature and volume of export and import trade influence in various ways the level and real character of domestic business. This is especially true in the case of a highly industrialized country such as the United States.

Even though the foreign trade of a nation may appear small as compared to its total national income, it has been demonstrated that a nation cannot long be prosperous when the rest of the world with which it trades is suffering from depression. Disturbances arising in one country tend to spread to others, and involve their economic entities.

One view which is still expressed in various quarters suggests the simple solution of keeping both exports and imports at an absolute minimum. This view would support a maximum degree of national self-sufficiency. Such a policy ignores the nature of the world we live in and disregards the economic and technological advancements of recent decades. We live today in a world so closely integrated, in which the balance between world-wide supply and demand is so delicate, that there must be an increasing flow of goods and services.

Out of the past world struggle has arisen a changed conception of foreign trade in its relation to domestic economy, a belief that trade "is a two-way street"; that in the final analysis imports finance exports. Hence, profiting from past experience, we need to view international trade in terms of benefits in which each nation may share equitably. One nation's exports are another's imports. Sound economic conditions must prevail at each end if trade maladjustments are to be avoided.

International trade, of course, is complicated by national frictions frequently disrupting the free flow of commerce in one part of the world or another. In spite of the repeated attempts to stabilize world trade, there appears to be little prospect in the immediate future that the world will establish any mechanism to accomplish that end. To illustrate: in earlier times barter was the accepted method of exchange. In what we believed to be more enlightened times, barter yielded to the use of gold and silver as means of settling international balances, but this device in its turn has failed for the simple reason that some nations have obtained a monopoly of the accepted "exchange." Basically, the suspicions that nations hold for each other prevent establishment of an enduring clearing house for international trade balances-a conclusion supported by history.

\section{Struggle for Domination of Trade}

The struggle between industries within a nation to gain trade advantages is indeed great, perhaps greater than between nations. This is particularly true in the case of industries producing products which can be used for the same purposes interchangeably. Segments of society, be they producers, distributors, or consumers, fight 
one another in the determination of policies by their respective states as to degree of protection for domestic producers or as to opening of domestic markets to foreign producers. The "general will" of the whole people exerts itself, however, in the final decision-this is an age-old struggle.

In contrast to the struggle between industries, each nation theoretically seeks maximum production and full consumption for its citizenry. Foreign traders insist. that the elimination of trade barriers would aid in freer international trade and go a long way toward assuring increased production, exchange, and consumption of goods, and a stable and harmonious world.

In spite of the incongruous characteristics of the various segments of society, states have emerged according to geographical areas, representing the people therein, with the general objective of assuring its citizenry preferable security. This objective leads to a race for a dominating position in international trade affairs, and frequently results in commercial warfare and economic destruction. Such economic warfare between countries often exposes the conflicts between the "have and have-not," with the "have-nots" struggling to gain access to strategic areas of supplies.

\section{Trade Characteristics}

In an ideal world, countries should guarantee all others "open door" treatment with respect to acquisition of foodstuffs, raw materials, and markets. Proposals now under consideration by different nations are designed to accord all nations opportunity to buy and sell in world markets on terms of complete equality with all other nations. Equality of treatment respecting foodstuffs and raw materials would embrace not only the right to acquire available supplies of such commodities on equitable terms, but would include also the right to develop resources necessary for the production of such commodities. This would mean, in other words, that producers of all countries be extended equality in obtaining concessions or other rights for the development of food and raw material resources. If raw material resources should be under a state monopoly, the political entity exercising such monopoly should undertake to make available an adequate supply at a reasonable price to meet the needs of all countries.

National and international aims should not be at variance if trade between nations is to be increased and encouraged-they might well be synonymous. Through the years, however, the trade policies of no country have been completely above the level of nationalism. Some countries have shown less nationalism than others. By and large, nevertheless, each country has been prone to establish trade barriers whenever its domestic economic position apparently was not to the immediate advantages of its producers. Seemingly, there has been an assumption on the part of the heads of governments that a national trade advantage must be evident in every business transaction with other countries for political reasons. Naturally, the populace agitates for, and prefers, immediate advantages over future promises. 
Collective measures are needed to safeguard the peoples of the world against threats to peace and to reach just settlements of disputes among nations; they must be based not only on international machinery to deal directly with disputes and to prevent aggression, but also on economic cooperation among nations with the object of preventing and removing economic and social maladjustments, of achieving equity between states, and of raising the standards of living among all people.

Nations generally adopt commercial policies suitable to their needs and stage of development. In the case of the United States, practically all of the functions for the control and promotion of international trade have been performed in some degree by the Federal Government without too much regard for the peculiarities of the individual states.

\section{U. S. AIMS AND INTERESTS}

The aims and interests of the United States in foreign trade have not always been consistent nor have they always been compatible with the best interest of international trade; while the United States has not resorted to all of the nationalistic programs pursued by some countries, it has used most of the common practices to "improve" its trade position.

The present commercial policy of the United States with respect to foreign trade is reaching a stage in its development at which the desire to promote the full postwar recovery of our international commerce is definitely in the foreground. It is partly the outgrowth of the nation's policy preceding the recent world crisis, partly the result of the emergency changes dictated by the war here and abroad, and partly the result of an effort to forecast the needs of the postwar.

The United States is fully aware of the variety of economic systems. Our policy seeks to make it possible for those systems to meet in the market place without conflict, to the advantage of each other's prosperity and welfare. Furthermore, it aims to make real the principle of equal access to the markets and raw materials of the world-this is to contribute to the effective growth of international confidence and solidarity, and thus to the preservation of peace.

The foreign trade aims of the United States are to find world markets for our domestic products, and in return, it is necessary to open our markets to foreign producers, sufficient to an "essential balance of trade." In the execution of such an objective, the trade interests of the United States extend to the promotion of conditions throughout the world which are compatible to the continuation of our free enterprise system. Furthermore, our foreign trade policy tends to the end that all foreign commercial transactions be conducted in a climate which protects producers and consumers from foreign discrimination.

Thus, the intensification of a mutually sound trade policy with foreign trading areas would be a feasible gesture, and a necessary one, if we are to protect our standard of living, and in so doing help others build against the destructive economic forces which have often dominated international trade relations in the past. 
Our present aim and interest, both nationally and internationally, is to relieve and to improve the sorry plight into which the past war has thrown the trade areas. It has been contended that the United States can advantageously forward its position among the nations of the world by extending liberal financial and trade assistance and cooperation. It is believed that through loans and credits, we can be instrumental in easing world exchange positions, making possible the purchase from our country of goods sorely needed to maintain trade equilibrium and a higher level of current consumption and employment. The national interest displayed at this time in corrective international trade aims can do much toward future economic security.

Trade Barriers

The foreign trade aims and interests of the United States have been definitely influenced by external conditions, such as trade barriers, just as other countries have felt the effect of our trade decisions. They are enumerated here with some comment on their characteristics in order to implicate the aggregate weight of their forces.

Trade policy involves many elements. Tariffs, quotas, subsidies, commodity agreements, trade restrictions, cartels, exchange and credit controls, monopolies, and intervention by political entities-all constitute a panorama of international economic scenery.

Tariff. Tariff is one of the earliest forms of trade barriers adopted by nations to protect their respective domestic producers against foreign producers; the practice has had a long history, with varying degrees in intensity of use and as to amounts of rates. Tariff laws are government impositions. People condone tariff laws which give them benefits, but they often find tariffs troublesome when they are imposed by governments of other nations.

In many cases tariff rates have been so high that trade affected thereby is prohibitive. Consequently, potential trade between nations is always an unknown quantity; most of the trade of countries with high tariff has been in commodities that have been admitted without tax or with a rate of tariff so low that the importing country could purchase the commodity, pay the tariff, and still get the commodities more cheaply than they could be produced within the same country.

A nation adhering to the protective tariff policy may develop not only industries having a comparative cost advantage; it may also produce commodities that have unfavorable cost in comparison with the cost of producing them abroad and in comparison with the cost incurred in the production of other commodities within the nation.

Believers in freer trade, or tariffs for revenue only, hold that the development of industries producing commodities moving in international commerce should be limited to industries possessing cost advantages; that the free movement of all merchandise in international commerce should be encouraged; and that consumers are at all times entitled to purchase all importable products at prices determined by world conditions of supply and demand-to import such of them as can be obtained to advantage. 
Protectionists believe that tariffs are necessary in order to develop infant domestic industries, to increase economic independence of a nation, to prevent unfair dumping, and to give diversification to our industry-all of which is felt to assure maximum employment, higher standards of living, and some security against economic recession.

From the point of view of the international trader, all excessive and unnecessary tariff rates should be eliminated. Where nations insist on the need of tariff duties either for protective or revenue purposes, the duties should be only moderate in amount. The aim should be the greatest possible exchange of goods among nations on the basis of comparative costs. Taxes other than tariff rates should not be imposed on imports except to offset excise taxes levied on competing domestic products. They should never be used for the purpose of furnishing additional or extra-tariff protection to domestic producers.

The United States Government, from the same point of view, should pursue a constructive, liberal, and realistic tariff policy, in order to encourage other nations to refrain from excessive and unreasonable tariffs. At the same time, our tariff laws should not only assure reasonable protection for American industries, including branches of agriculture, subject to destructive competition from abroad and of benefit to any considerable section of the country, but should also have adequate provisions for meeting direct or indirect discriminations by other countries against American trade.

Trade Quotas. A more absolute barrier in the restraint of foreign trade is a quota system, to the extent of its application. The disadvantages of a quota system are many. The operation of such a system is technically complicated and necessitates an elaborate statistical set-up for accurate and swift dissemination of information, necessary for day-to-day regulations, both to customs officers and to the foreign and domestic merchants planning for shipments. The setting of the quota involves delicate decisions as to the evaluation of the industry receiving quota protection and the consumption needs of the country.

A quota system necessitates increased government intervention in business affairs both in its requirements for statistical information and in its direction of purchases or sales. The application of such a scheme undoubtedly offers opportunity for national favoritism in the distribution of licenses as well as in the imposition of the quotas themselves.

On the other hand quotas have proved themselves helpful in the case of a trade emergency or for a commercial policy based on bargaining or economic planning. Whether or not they ultimately will become an accepted and orthodox technique in the control of foreign trade, their continuance for a span of several years is assured by their incorporation in a wide net of commercial treaties now in existence and in the process of being made.

Subsidies. Subsidization of foreign trade activity by governments is another 
method commonly used to gain trade advantages by artificial means. It is a device that can be used to aid certain branches of a nation's economy to compete in international markets caused by economic dislocation brought about by manipulation of currency, unfair trade balances, or differences in the standard of living between countries.

Export Controls. Some countries adopt export controls in case of war or other international emergencies to prohibit certain other countries from importing particular strategic commodities deemed helpful to them in their preparation for war or in their attempt to gain political or economic influence over rival states.

Collective Activity to Gain Foreign Markets. To gain markets, exporting countries have resorted to many devious practices, cooperatively on the part of the producers concerned, or by the government of the producers in their behalf. To illustrate, private trade promotion agencies have been established to aid their respective clientel in foreign trade by preparing trade lists containing world trade opportunities including the names of buyers and agents, credit reports, registration of trade-mark in any country, payment of overdue accounts, and preparation of foreign commerce handbooks. Governments have established overseas trade offices to guide the new and prospective foreign traders, statistical analyses, and the like.

Trade Agreements. Commercial agreements have been emphasized of recent times as a procedure to stimulate freer international trade by removing in particular, all trade barriers in the form of excessive tariffs. Tariffs had been used extensively in the I920's up through the early r $930^{\circ}$ 's as an instrument of economic warfare by most of the nations participating in international trade. When the world depression set in in the early I930's, various nations began to turn to commercial trade agreements in an effort to cut away trade barriers and release the flow of international trade.

The United States program of reciprocal trade agreements was initiated in 1934, and was continued with little or no change until 1945. At that time Congress renewed the act for three additional years and provided further that our own tariff rates could be reduced as much as 50 percent below the levels of January, r945, which meant a possible reduction of 75 percent in all from the rates of the original Hawley-Smoot schedules still in effect in 1934. As enacted in 1934, as an amendment to the Hawley-Smoot Tariff Act, the primary purpose of the Reciprocity Trade Agreements Act is to expand the foreign market for American products "as a means of ... overcoming domestic unemployment, ... increasing the purchasing power of the American public, and in establishing and maintaining a better relationship among various branches of American agriculture, industry, mining, and commerce." It aims to accomplish this expansion of exports in two ways: $(x)$ by inducing foreign nations to modify or remove burdensome import restrictions on American products, and (2) by reducing our own customs duties and restrictions on selected imports into the United States.

Commodity Agreements. Intergovernmental commodity agreements although subject to public control and therefore perhaps less objectionable than private trade 
cartels, nevertheless restrict the supply and increase the cost of products to consumers. Hence, if their operation is to be tolerated in a free economic system, their application should be restricted to commodities which are subject to chronic surpluses. An effort should be made by the nations participating in such agreements to shift productive facilities from the production of the surplus commodity to other economic activities and to adjust their economies so as to prevent the production of surpluses of the commodity in question, with a view to eventual elimination of the governmental control over the production and marketing of such commodity.

Economic Self-Sufficiency. The doctrine of national economic self-sufficiency has been a definite threat to international trade. It implies that there is a necessary conflict between domestic and foreign commerce, that a nation must decide to have either the one or the other, but not both. But, according to some experts, there is no sound reason why industries which can readily produce in excess of domestic requirements should not export their surplus output to world markets, or why users of consumer's goods and industries requiring raw materials should be limited to domestic sources of supply.

The doctrine of economic self-sufficiency further implies that a nation can readily limit imports to a few staple articles which from their nature carnot conceivably be produced at home. It assumes that imports cannot be increased without damaging desirable national industries and the nations' labor. It ignores the now generally understood fact that if imports were restricted to the point urged by those who favor this doctrine, our exports would be virtually destroyed by the absence of a dependable basis for the settlement of import bills.

Commercial Arbitration. Special importance should be attached to the friendly solution of disputes and difficulties originating in international commercial transactions. There are noteworthy advantages to arbitration because of its economy and the usefulness of an expeditious means of settlement. Acceptance of an agreed-upon jurisdiction for arbitral proceedings, and uniformity and validity of arbitration clauses, are also important.

All commercial disputes should be settled by arbitration if possible. Such arbitration, however, should be entirely voluntary. Arbitration provisions could be advantageously written into all commercial contracts. It offers a possible solution to complex postwar trade controversies.

Cartels. The cartel is a.kind of alliance between business rivals. As experience discloses, firms engaging in like pursuits have banded together to restrain competition by fixing selling prices, by dividing the world into exclusive markets, by curtailing production, by suppressing technology and invention, by excluding their rivals from particular fields, and by boycotting outsiders-all of which destroy fair competition and fair trade, discourage new businesses, hurt small business, and levy an unjust toll upon consumers.

Cartels arise from a desire to avoid competition which tends to lower prices, 
reduce profit margins, threaten the existence of high cost producers, and diminish established capital values.

Goods can surmount a tariff if they pay the duty; they can enter despite a quota if they are within it. But when a private agreement divides the markets of the world among the members of a cartel, none of those goods can move between the zones while the contract is in force. Clearly, if trade is to increase as a result of the curtailment of government restrictions, the governments concerned must make sure that it is not restrained by private combinations. Cartel aims often run contrary to the policy of a national state, and under such circumstances may even circumvent or nullify national objectives.

Control of cartels necessarily rests with member governments, but in some instances governments have given a degree of protection or support to cartels. On the other hand, many countries are wholly at the mercy of international cartels in broad fields of business activity. In the United States, enforcement against their operation is undertaken by judicial proceeding under the anti-trust laws. But many activities and operations of such business combines are immune to prosecution under the anti-trust laws of this country; they are in a position to shift from one country to another so as to avoid difficulties and maintain secrecy for the efficient conduct of their own affairs. Accordingly, the international coordination of national policies is the most desirable means of meeting the problems raised by international cartels.

\section{Equal Treatment to Foreign Business}

For a freer international trade it is essential that corporations or firms entering a foreign country to do business be given equality of treatment in all respects. If discrimination should be allowed, in final analysis there would be no limit this side of total destruction of all foreign businesses within a state. The foreign economic policy of the United States embraces the responsibility for safeguarding and protecting the interests of American enterprise abroad through every political and economic means at the government's disposal. This responsibility lies in the area of assuring the safety and security of foreign investments against confiscation or discrimination in any form.

\section{Monetary Problems}

The medium of exchange is one of the most significant tools in influencing the free flow of international trade. Its effects can be caused and remedied by manipulations of international monetary systems. The depreciation of currency by one country might practically wipe out the trade balance of another. The operation of a sterling bloc can easily prevent a free flow of trade and prohibit the country in need of credits from realizing such assets.

In this and in many other ways a country might fail to acquire or lose its favorable balance of trade; consequently, leaving itself without credit (foreign exchange) with which to finance purchases. To overcome this situation, international monetary agreements (such as the Bretton Woods, and operations of the Export- 
Import Bank) are helpful and sometimes complete. It must not be overlooked, however, that while international monetary manipulations can correct an international trade stalemate, it can just as easily become a peril thereto.

Nations should not engage in competitive depreciation of their currencies as a means of gaining foreign trade advantages. The break-down of the international monetary system, and the complicated system of control developed in its place, were largely a result of the depression of the early thirties. Faced with a declining world demand, each country tried to get a larger share of the total world exports. In the ensuing struggle for markets, all sorts of restrictive and discriminatory monetary controls were adopted, with no consideration of their long-run consequences. To illustrate: The United Kingdom gained a temporary advantage in export markets by reducing the price of the pound sterling. Other countries finding themselves undersold by British exporters, retaliated by reducing the prices of their own currencies. Once started, currency depreciation thus tended to spread throughout the world and resulted in complete currency control by some countries as a means of restoring a balance.

To overcome such state of affairs, the International Monetary Fund created under the Bretton Woods Agreement has been proposed to prevent depreciation of currency. The article of agreement pertaining to the Fund would permit a member nation to depreciate the value of its currency within specified limits under conditions largely created by the nation itself. The administrators of the Fund should establish standards which would dissuade a nation from resorting to currency depreciation for the correction of a disequilibrium in its international financial situation which is primarily due to the adoption or continuance by such nation of unsound financial or other economic policies.

Monetary Blocs. The difficulty with economic blocs is that parties thereto are forced to trade almost exclusively among themselves, even though the price and delivery by another country might be more favorable. The formation of a bloc such as the sterling bloc, not only closes the doors to the sale of American products in that area, but it also forces the creation of other economic blocs which in turn trade and exchange goods largely among themselves. A Russian bloc, a dollar bloc and perhaps others would emerge, each endeavoring to strengthen its position by inducing or high-pressuring marginal countries to leave one bloc and join another. This means, of course, that governments become the dominating factor in world trade. Regulations and control of exports, imports, and foreign exchange are inherent in the system. The international flow of goods under these circumstances is not measured by demand and price and quality of goods, but rather by artificial regulations resulting from political considerations and a shortage of particular currencies. This results inevitably and unhappily in the total volume of world trade being drastically reduced.

Foreign Investments. The benefits a nation derives from loans and investments depend upon the ability of the recipient countries to service and repay them. The 
benefits that the recipients obtain depend upon the productivity of the new capital. Hence, it is important that the volume of our new loans and investment abroad be related directly to the capacity of the recipient countries to put additional capital to productive use.

Financial Agreements. Countries frequently utilize the various types of financial trade agreements to overcome temporary unfavorable trade relationships, or to accomplish specified objectives, such as the lend-lease agreements which were set up to meet a critical crises brought about by World War II.

The proposed financial agreement between the United States and Great Britain has been reached on the broad principles of commercial policy for which the two governments will seek generally international support. These arrangements propose to put an end to the fear of an economic divided world; would make possible the expansion of employment, and of the production, exchange, and consumption of goods; and would bring into being for the first time, a common code of equitable rules for the conduct of international trade policy and relations. Such negotiation would relate to tariffs and preferencies, quantitative restrictions, subsidies, state trading, cartels, and other types of trade barriers.

Additional financial trade agreements are now being sought by other governments. The commercial policy proposal of the United States announced in conjunction with these financial agreements reflect basic American thinking on international economic relationships. Taken as a whole, the proposals represent an implied knowledge of the proposition that our largest and most profitable long term share of over-all international trade will be obtained when that trade is conducted in accordance with the "live and let live" principle of widespread and mutual benefit.

Export-Import Bank. Another source of credit to foreign countries is available through the Export-Import Bank set up by Congress to aid in the "financing and facilitating of exports and imports and the exchanges of commodities between the United States and any of its territories or insular possessions and any foreign country or the agencies or nationals thereof." This Bank has broad powers to do a general banking business and to make practically any type of loan, without limitation as to the amount of loans to any one borrower, so far as these are in harmony with the general purpose.

The International Bank of Reconstruction and Development. One of the most important proposed sources for international credit and stabilization of currencies is to be found in the Bretton Woods Plan which became effective at the end of I945 as thirty-five of the forty-four nations which met in Bretton Woods July, I944, approved the plan and became members. The International Bank of Reconstruction and Development with a proposed capital of $\$ 9,100,000,000$ has as its objective to make and guarantee loans to member countries for their internal economic development which, in turn, will promote commerce. The Stabilization Fund with a proposed total of $\$ 8,800,000,000$ was set up to stabilize exchange between nations, an indispensable factor if the channels of business are to function freely. In adhering 
to the Agreements, the United States accepts the highest quota of any country$\$ 2,750,000,000$ to the Stabilization Fund and $\$ 3,175,000,000$ to the Bank.

\section{Political Trade Barriers}

In the development of international trade relationships, the rivalry decisions on the part of some countries to gain artificial advantages over others have resulted into the establishment of what might be called "political" trade barriers. These have taken various forms, the objective of the decreeing governments always being to place the other countries at an economic disadvantage. Few countries have remained free of this accusation.

The following paragraphs will highlight some of these practices. First, imperialistic policies followed by some nations have resulted in the establishment of colonial empires consisting of colonies, protectorates, or mandated territories, or some of each. In each instance, the mother country of the empire has used its colonies to its own enhancement, restricting them in trade privileges with other countries.

The United States advocates an idealistic treatment of colonial people by the suzerain. United States officials have expressed the hope that with a more orderly system of international trade in the postwar period, there will be a tendency for the welfare of colonies to be improved if they are permitted to export more freely their industrial raw materials.

As a general proposition, preferential arrangements between groups of nations or between a mother country and its dominions or colonies which give more favorable tariff treatment to the products of each other than to those of outside countries are objectionable. There are, however, some circumstances under which preferential arrangements would seem to be justified. Such arrangements might be permitted in the case of contiguous nations which are closely affiliated economically and whose prosperity would be increased by removal of tariff barriers between them. To be acceptable, such arrangements should meet certain justifications. The United States has tended in this direction in its dealings with Latin America.

One of the main arguments used against trade agreements is that they give no protection against activity by political units of the state to burden foreign trade. This discrimination takes various forms, namely: excise taxes, police power restrictions, and the like, all of which burden trade. The hurtful part of the matter is that there is a natural tendency for political divisions of the state to take such action. Even in a country as homogeneous as the United States, the existence of a sales tax in one state has created friction with adjoining states which have no comparable tax. Had it not been for the commerce clause in our Constitution, there would have developed an intolerable situation in inter-state commerce. Thus, some countries with which the United States has trade agreements, not so fortunate as to have a Constitution like the United States, find their respective political units decreeing retaliatory measures contrary to the intent of the trade agreements.

Much is being said about the creation of an economic climate in which free 
enterprise may operate. This world climate can only come into being and be maintained through cooperative action among governments. Our government alone cannot resolve all questions of international aims and interests.

We might consider at this point two methods of conducting foreign trade, selected arbitrarily for the purposes of this discussion. First, we have an outright system of state monopoly as employed by Russia. On the other side, we have free enterprise as used in the United States. The trade principles of these two economic systems are not necessarily compatible. Hence, as the counterpart of tariff reduction and other actions to encourage an expansion of multilateral trade by other nations, countries having a complete state of monopoly of foreign trade should undertake to trade with other countries on a non-discriminatory basis. All countries regardless of their economic systems, if freer international trade is desired, should cooperate to the extent of their political ability to produce a climate suitable for better trade relations between each other. Finding the proper approach to this accomplishment is perhaps the most important task in international trade and financial relationships confronting the world today. For the safety of free enterprise, nevertheless, the United States seemingly is justified in discouraging trade with state monopolies and in facilitating direct trade with individuals in the countries concerned.

This principle if pursued far enough would discourage and finally eliminate the presence of foreign purchasing missions in this country. To meet the challenge of free enterprise, foreign trade must be restored to private channels as rapidly as possible.

Regional pacts and spheres of influence for foreign trade purposes can be used by a country or several countries, as is frequently the case, to enhance its (or parties to the pact) trade position as opposed to its competitors. Although it is evident that regional pacts must result in some immediate dislocation of trade with outsiders, even non-signatories should gain in the long run from any general betterment of economic conditions arising out of them. They should be condemned as undesirable from an economic point of view, however, when they divert trade from producing markets best suited to supply needs or when they discriminate unjustifiably.

Some countries have used tolls, others have used canal franchises, and still others have acquired all possible spheres of control, to gain foreign trade advantages. In the case of communications, some nations have exerted their sovereignty to gain comparative preference. In transportation by water and air, countries in a position to exert control have done so. All of these have been used to acquire better trade balances, or selfish economic gains. Fortunately, the United States has used its superior international financial position to overcome some of these barriers.

\section{Postwar Trade OutLook}

These trade barriers enumerated above as practiced by other countries have not only been influential in the determination of the American foreign trade policy, but in some instances have forced our hand in the adoption of particular retaliatory 
barriers. On the other hand, the "protective measures" adopted by the United States have had a similar effect on other countries. Our foreign trade practices through the years under such uncontrollable influences, could have been a great factor in the formulation of our trade aims.

No single trade barrier can be accredited with a force sufficient to change the principles on which American trade policies are based, but all of them together through the years have entered into the formulation of a trade policy in conformity with international trade aims. Obviously each country desires to benefit its own people, but a cutthroat competitive race in that direction, leading to an asserted nationalistic policy, would in the long run be to the disadvantage of its citizens. Acknowledgment of this fact by the chief trading nations of the world would admit the need of foreign trade policies conducive to freer trade.

An international trade program cannot succeed unless the economic conditions producing trade conflicts are prevented from recurring in the future. Hence all of these factors influencing foreign trade policies should be examined and weighed with an eye to a modification of them to insure a freer international trade.

The object of a program to reduce trade barriers is to prevent future world depressions. Our postwar commercial policy is thus closely connected with our domestic employment and monetary policy. It is safe to predict that all postwar policy whether international or domestic, economic or political, will have two general aims: (I) the establishment and maintenance of peaceful conditions, and (2) the provision of a high and expanding level of income and employment both at home and abroad. Agreement upon these two broad purposes is so widespread that virtually all proposed policies or programs must be judged by the contributions which they make to world peace and to high income and employment. 